\title{
Field Control of Synanthedon myopaeformis Borkh and Zeuzera pyrina L. Using Entomopathogenic Nematodes, Insecticides and Microbial Agents
}

\author{
EL-Ashry R. M. A. ${ }^{1}$; El-Sheikh M. F. M. ${ }^{2}$; Azazy A. M. ${ }^{3}$ and Arafa Olfat E. ${ }^{3}$ \\ ${ }^{1}$ Plant Prot. Dept., Fac.Agric., Zagazig Univ.,Egypt. \\ ${ }^{2}$ Plant Prot. Dept., Fac.Agric., Tanta Univ., Egypt. \\ ${ }^{3}$ Plant Prot. Res. Inst., Agric. Res .Center Dokki, Egypt. \\ email: mrmaa2010@yahoo.com
}

\begin{abstract}
Three field trials were carried out to evaluate the efficacy of two local strains of entomopathogenic nematode, Heterorhabditis bacteriophora ( Ar-4 and Ht strains) isolated from EL-Arish and Giza in Egypt and two commercially available nematode species, Steinernema carpocapsae (All strain) and H. bacteriophora (HP88 strain) for the control of fruit tree borers, Synanthedon myopaeformis and Zeuzera pyrina on apple trees. The entomopathogenic nematodes (EPNs) were used alone or combined with recommended dose of the microbial pesticide, Bacillus thuringiensis (Diple2X), and insecticides, diazinon and phenthoate. The obtained results showed that the combined EPNs with insecticides were more effective as injection technique than spray method. Mortality percentages of $S$. myopaeformis ranged between 47.61 to $88.88 \%$ in the injection treatments while in the spraying one it ranged between 37.14 to $74.07 \%$. In comparison between the efficacy of native and imported entomopathogenic nematodes in controlling $Z$. pyrina using spray technique, percentage mortality resulted from the combination of native nematodes i.e. H.bacteriophora (Ht strain) and $H$. bacteriophora (Ar-4 strain) and insecticides either penthoate or diazinon reached $69.23 ; 64.00$ and $22.72 ; 64.18 \%$, respectively. Whereas, percentages mortality were 44.44; 50.00 and 52.94; 54.16\% with $S$. carpocapsae (All strain) and H. bacteriophora (HP88 strain), respectively. The susceptibility of $Z$. pyrina to the nematode species differed greatly according to the nematode species used either alone or in combination with the recommended dose of $B$. thuringiensis. The entomopathogenic nematode $H$. bacteriophora (HP88 strain) was more virulent than $S$. carpocapsae (All strain) in controlling $Z$. pyrina with percentage mortality reached 77.5 and $62.1 \%$, respectively.
\end{abstract}

$\overline{\text { Key words: Synanthedon myopaeformis, Pathogenicity, Zeuzera pyrina, Steinernema, }}$ Heterorhabditis, Compatibility.

\section{INTRODUCTION}

Borer insects (Synanthedon myopaeformis Borkh and Zeuzera pyrina L.) are most important pests since they attack a large number of shrubs and deciduous tree species including apple, pear, peach, cherry, olive as well as walnut trees in Egypt (Abdel- Kawy et al.,1988). Control of the leopard moth has many difficulties, since the larvae escape from direct exposure to pesticides because they live inside branches 
and trunks (Shamseldean et al., 2009). Chemical pesticides are widely used to combat pests. However, increasing awareness of environmental and human health associated with chemical pesticides are forcing scientists to search for less toxic pest management methods.

Finding safer alternatives to chemical pesticides is especially urgent for borer insects ( $S$. myopaeformis and Z. pyrina) of fruit trees. In the cryptic habitats, biological control agents especially, the genera Steinernema and Heterorhabditis of entomopathogenic nematodes (EPNs) could be considered appropriate candidates against these pests. Since, Z. pyrina larvae were susceptible to infection by $S$. carpocapsae and H. bacteriophora under laboratory and field conditions (AbdelKawy and El-Bishry, 1992). Using low impact pesticides or other bioagents like Bacillus thuringiensis reduced rates of pesticides and could achieve adequate control through minimizing the adverse effects of pesticides (Mannion et al ., 2000).

The objective of the present study was to determine the relationship between application methods of native and commercial entomopathogenic nematode, diazinon and phenthoate as insecticides as well as B. thuringiensis either alone or mixed in controlling the clear-wing moth, S. myopaeformis and the leopard moth, Z. pyrina on apple trees.

\section{MATERIALS AND METHODS}

\section{1-Rearing Technique:}

\section{a- Rearing of the greater wax moth, Galleria mellonellaL.}

Last instar larvae of G. mellonela (Lepidoptera: Pyralidae) were separated from bee hives for nematode culture, leaving small sized larvae for moth emergence and egg laying. Fresh laid eggs were transferred to modified artificial medium contained honey, wheat bran, glycerol, soy flour, milk powder, dry yeast, and honey bee wax in glass jars kept at $27^{\circ} \mathrm{C}$.(Ekmenet al., 2010).After reaching last instars, they were taken out from the diet and used for storage and nematode isolation/multiplication according to Kaya and Stock (1997).

Heterorhabditis bacteriophora (HP88 strain), Steinernema carpocapsae (All strain) and two local strains isolated from EL-Arish and Giza, Egypt. H. bacteriophora (Ar-4) and $H$. bacteriophora $(\mathrm{Ht})$, respectively were multiplied and harvested from greater wax moth larvae (Woodring and Kaya, 1988) and infective juveniles of these nematodes were washed in three changes of distilled water (Dutky et al.,1964). Nematodes were stored at $13^{\circ} \mathrm{C}$. for up to two weeks prior to use in experiments. All experiments were conducted at $25 \pm 4{ }^{\circ} \mathrm{C}$.

\section{b-Isolation of native entomopathogenic nematodes:}

Baiting technique of G. mellonella modified after Bedding and Akhurst (1975) was followed. Soil samples infested with nematodes were placed in plastic bags and transferred to the laboratory. From each bag a soil sample was thoroughly mixed and then divided into 4 portions. Fifty grams from each were put in 14-cm Petri-dish. Five G. mellonella late instar larvae, were placed onto the soil surface and the dishes were kept at $25^{\circ} \mathrm{C}$. As mature wax larvae tended to move upward the Petri-dishes were turned upside down every 24 hours, so that the confined larvae were also allowed to pass through the soil in order to increase the possibility of their encounter with the nematodes. Dishes were examined 5 days later, and the dead larvae, which were suspected to be nematode-infected, were picked up carefully, rinsed several times 
with distilled water and incubated at $25^{\circ} \mathrm{C}$.in an extraction plates. Each plate contained only one dead larva. The original method described by Dutky et al. (1964) was used with some modifications, where the dead larvae were placed on a special fabric muslin cloth to avoid the disintegration of the filter papers. Nematode juveniles were maintained in $0.1 \%$ formaldehyde until identification. Two isolates designated as H.bacteriophora (Ar-4 strain) from EL-Arish and H. bacteriophora (Ht strain) from Giza were exracted from soil samples.

\section{c-The biocontrol agent Bacillus thuringiensis:}

The Diple 2X Bacillus thuringiensis var.kurstaki; $32000 \mathrm{IU} / \mathrm{mg}$ was used in the present study with the recommended dose of $1 \mathrm{~g} /$ liter. The mixtures of the nematodes and the bacterium were performed by mixing the nematode strains of H.bacteriophora (HP88 strain), S. carpocapsae (All strain) and H.bacteriophora (Ht strain)(2000 $\mathrm{IJ} \mathrm{s} / \mathrm{ml}$ for each) with the recommended dose of the bacterium.

\section{2- Field Experiments:}

Field Experiments were carried out in four different farms during three consecutive years of 2014, 2015 and 2016 to determine the efficiency of certain native and imported strains of entomopathogenic nematodes with two application methods against two species of fruit tree borers, the leopard moth Zeuzera pyrina and the clearwing moth Synanthedon myopaeformis on apple trees. Also, these strains of nematodes were used at two concentration (1500 and $3000 \mathrm{IJs}$ ), separately or $1000 \mathrm{IJs}$ when combined with two insecticides (Diazinon and Phenthoate; $3 \mathrm{ml} /$ liter water) or the microbial insecticide B. thuringiensis (Diple2X at concentration of $32000 \mathrm{IU} / \mathrm{mg}$ for evaluating the efficacy of these combinations against these borers. The field experiments were conducted as follows:

A-The first experiment took place in two districts, EL-Mansouria locality in Monofyia Governorate and EL-Marwa\& EL-Zeitoun farms in Giza Governorate. Heavily $S$. myopaeformis infested apple trees were sprayed or injected by water suspensions of two strains of imported entomopathogenic nematodes, $S$. carpocapsae (All), $H$. bacteriophora (HP88) and two local strains isolated from EL-Arish and Giza in Egypt, H.bacteriophora (Ar-4) and H. bacteriophora (Ht) at two concentrations of each (approximately 1500 and $3000 \mathrm{IJs} / \mathrm{ml}$ distilled water). Also, combinations of entomopathogenic nematodes and either Diazinon (basudin) or Phenthoate (cedial L60) at a concentration of $3 \mathrm{ml} /$ liter of water were undertaken on infested apple trees. For spray and injection techniques, one concentration of nematodes $(1000 \mathrm{IJ} / \mathrm{ml})$ was used spraying technique using a handle sprayer of 2.5 liter was directed towards the active galleries, whereas the injection was carried out using 50cc syringe.

B-The second experiment was carried out in both previous areas on heavily $Z$. pyrina infested apple trees. The infested apple trees were sprayed only by 1500 IJs water suspensions of two strains of imported entomopathogenic nematodes, $S$. carpocapsae (All) , H. bacteriophora (HP88) and two native strains, H.bacteriophora (Ar-4) and $H$. bacteriophora $(\mathrm{Ht})$ at concentrations of $3000 \mathrm{IJs} / \mathrm{ml}$ distilled water only. Also, combinations of abovementioned nematodes and either diazinon or phenthoate at a concentration of $3 \mathrm{ml} /$ liter of water were undertaken on infested apple trees.

C-The third experiment was conducted at EL-Marwa \& EL-Zeitoun farms in Giza Governorate on apple trees that were heavily infested with Z. pyrina. In such independent experiment, S. carpocapsae (All strain), H.bacteriophora (HP88) and H.bacteriophora $(\mathrm{Ht})$ in combinations with B. thuringiensis (Diple 2X), were 
evaluated by spray technique against $Z$. pyrina at the beginning of May 2013. The same treatments were repeated in the preultimate week of November 2014.

For all experiments the check or control trees, were treated with water and all treatments were carried out before sunset to avoid excessive evaporation and direct sunlight (UV). The treatments were replicated 3 times, since injection technique was conducted only once but spraying was repeated 3 times with one week interval.The treated trees were weekly inspected after application, where the galleries that had new exploded frasses, were considered active beside the actively moving larvae. Also, some randomly galleries in the trunk and main branches, were inspected by using a sharp knife and (about $50 \mathrm{~cm}$ long) a flexible wire to about $50 \mathrm{~cm}$ long. Mortality percentages were calculated according the following formula:

No. of active galleries before treatment - No. of active galleries after treatment

No. of active galleries before treatment

\section{3- Statistical analysis:}

The experiments were carried out in a completely randomized design with 3 replications for each treatment. Data were subjected to analysis of variance (ANOVA) using MSTAT version 4 (1987). probability. Means were compared by Duncan's multiple range test (Duncan, 1955) at $\mathrm{P} \leq 0.05$

\section{RESULTS AND DISCUSSION}

Data in Table (1) showed the impact of entomopathogenic nematodes viz. $S$. carpocapsae (All strain), H. bacteriophora (HP88 strain), H. bacteriophora (Ar-4 strain) and $H$. bacteriophora (Ht strain) alone or in combination with insecticides either diazinon or phenthoate on S. myopaeformis infesting apple trees. Two different methods of nematode application were used (spray and injection). It was found that combination of $S$. carpocapsae and diazinon gave the highest effect with average mortality of $72.17 \%$ followed by $S$. carpocapsae and phenthoate with average 64.70 $\%$ whereas; $S$. carpocapsae spray alone had the lowest effect with average mortality $50.55 \%$. Injection technique proved to be more effective than spray, $S$. carpocapsae and phenthoate gave the highest effect followed by $S$. carpocapsae and diazinon with percentage mortality of 76.47 and $74.07 \%$, respectively. Concerning heterorhabditid nematodes, H. bacteriophora (HP88 strain), H. bacteriophora (Ar-4 strain) and $H$. bacteriophora (Ht strain) used to control larvae of $S$. myopaeformis on apple trees, mortalities showed that $H$. bacteriophora (HP88 strain) alone or in combination with the used insecticides were more effective when compared with H.bacteriophora (Ar-4 strain) and H. bacteriophora (Ht strain) alone or with insecticides, diazinon and phenthoate. Average percentages mortality for application of H.bacteriophora (HP88 strain) were 46.02 and 46.76 when used alone as spray and injection techniques, respectively. In combination between H.bacteriophora (HP88 strain) and insecticides, average percentages mortality were 65.66 and 74.69 with diazinon and phenthoate, respectively. Whereas the parallel values with $H$. bacteriophora (Ar-4 strain) were $36.23,43.66$ when used alone by spray and injection techniques, respectively and $65.17 ; 51.57$ in combination with the two insecticides, respectively. As injection treatments, among the four nematode strains, $S$. carpocapsae (All strain) was the most effective followed by H.bacteriophora (Ht strain), H. bacteriophora (HP88 strain) and H. bacteriophora (Ar-4 strain) with average mortalities 56.47, 54.65, 46.76 and 43.66, 
respectively. Whereas the two insecticides caused 67.65 and 41.15 average mortality and phenthoate was the least effective insecticide.

Table 1. Comparison of entomopathogenic nematodes and insecticides applied with two different methods for controlling Synanthedon myopaeformis Borkh on apple trees.

\begin{tabular}{|c|c|c|c|c|c|c|}
\hline \multirow{2}{*}{ Treatments } & \multirow{2}{*}{$\begin{array}{l}\text { Applicatin } \\
\text { Method }\end{array}$} & \multirow{2}{*}{ Conc. } & \multicolumn{2}{|c|}{$\begin{array}{l}\text { No. of active } \\
\text { galleries }\end{array}$} & \multirow{2}{*}{$\begin{array}{c}\% \\
\text { Mortality }\end{array}$} & \multirow{2}{*}{ Average } \\
\hline & & & $\begin{array}{c}\text { Before } \\
\text { treatment }\end{array}$ & $\begin{array}{c}\text { After } \\
\text { treatment }\end{array}$ & & \\
\hline \multirow[t]{2}{*}{ S. carpocapsae (All strain) } & \multirow[t]{2}{*}{ Spray } & 3000 & $15 \mathrm{~d}^{*}$ & $9 \mathrm{bc}$ & 40.00 & \multirow{2}{*}{$50.55 \mathrm{abc}$} \\
\hline & & 1500 & $21 \mathrm{~cd}$ & $8 \mathrm{bc}$ & 61.90 & \\
\hline \multirow[t]{2}{*}{ S. carpocapsae (All strain) } & \multirow{2}{*}{ Injection } & 3000 & $17 \mathrm{~d}$ & $8 \mathrm{bc}$ & 52.94 & \multirow{2}{*}{$56.47 \mathrm{abc}$} \\
\hline & & 1500 & $15 \mathrm{~d}$ & $6 \mathrm{~cd}$ & 60.00 & \\
\hline \multirow{2}{*}{$\begin{array}{l}\text { S. carpocapsae } \\
\text { (All strain) +Diazinon }\end{array}$} & Spray & 1000 & $37 \mathrm{a}$ & $11 \mathrm{~b}$ & 70.27 & \multirow{2}{*}{$72.17 \mathrm{ab}$} \\
\hline & Injection & 1000 & $27 \mathrm{bc}$ & $7 \mathrm{~cd}$ & 74.07 & \\
\hline \multirow{2}{*}{$\begin{array}{l}\text { S. carpocapsae } \\
\text { (All strain) }+ \text { Phenthoate }\end{array}$} & Spray & 1000 & $34 \mathrm{ab}$ & $16 \mathrm{a}$ & 52.94 & \multirow{2}{*}{$64.70 \mathrm{ab}$} \\
\hline & Injection & 1000 & $17 \mathrm{~d}$ & $4 \mathrm{~d}$ & 76.47 & \\
\hline \multirow{2}{*}{$\begin{array}{l}\text { H.bacteriophora } \\
\text { (HP88 strain) }\end{array}$} & \multirow{2}{*}{ Spray } & 3000 & $34 \mathrm{c}$ & $18 \mathrm{a}$ & 47.05 & \multirow{2}{*}{$46.02 \mathrm{~cd}$} \\
\hline & & 1500 & $20 \mathrm{~d}$ & $11 \mathrm{c}$ & 45.00 & \\
\hline \multirow{2}{*}{$\begin{array}{l}\text { H.bacteriophora } \\
\text { (HP88 strain) }\end{array}$} & \multirow{2}{*}{ Injection } & 3000 & $38 \mathrm{~b}$ & $18 \mathrm{a}$ & 52.63 & \multirow{2}{*}{$46.76 \mathrm{~cd}$} \\
\hline & & 1500 & $22 \mathrm{~d}$ & $13 \mathrm{~b}$ & 40.90 & \\
\hline \multirow{2}{*}{$\begin{array}{l}\text { H.bacteriophora } \\
\text { (HP88 strain) +Diazinon }\end{array}$} & Spray & 1000 & $37 \mathrm{~b}$ & $15 \mathrm{~b}$ & 59.45 & \multirow{2}{*}{$65.66 \mathrm{ab}$} \\
\hline & Injection & 1000 & $32 \mathrm{c}$ & $9 \mathrm{c}$ & 71.87 & \\
\hline \multirow{2}{*}{$\begin{array}{l}\text { H.bacteriophora } \\
\text { (HP88 strain) }+ \text { Phenthoate }\end{array}$} & Spray & 1000 & $44 \mathrm{a}$ & $13 \mathrm{~b}$ & 70.45 & \multirow{2}{*}{$74.69 \mathrm{a}$} \\
\hline & Injection & 1000 & $19 \mathrm{~d}$ & $4 \mathrm{~d}$ & 78.94 & \\
\hline \multirow{2}{*}{$\begin{array}{l}\text { H.bacteriophora } \\
\text { (Ar-4 strain) }\end{array}$} & Snray & 3000 & $22 \mathrm{e}$ & $13 \mathrm{bc}$ & 40.90 & $3623 \mathrm{~d}$ \\
\hline & spray & 1500 & $19 \mathrm{f}$ & $13 \mathrm{bc}$ & 31.57 & a \\
\hline H.bacteriophora & Iniection & 3000 & $17 \mathrm{f}$ & $10 \mathrm{~d}$ & 41.17 & $4366 \mathrm{c}$ \\
\hline (Ar-4 strain) & injection & 1500 & $26 \mathrm{~d}$ & $14 \mathrm{bc}$ & 46.15 & $43.00 \mathrm{c}$ \\
\hline H.bacteriophora & Spray & 1000 & $41 \mathrm{a}$ & $24 \mathrm{a}$ & 41.46 & $6517 \mathrm{a}$ \\
\hline$($ Ar-4 strain $)+$ Diazinon & Injection & 1000 & $18 \mathrm{f}$ & $2 \mathrm{bc}$ & 88.88 & $05.1 / \mathrm{a}$ \\
\hline H.bacteriophora & Spray & 1000 & $35 \mathrm{~b}$ & $17 \mathrm{~b}$ & 51.42 & $5157 \mathrm{~h}$ \\
\hline$($ Ar-4 strain $)+$ Phenthoate & Injection & 1000 & $29 \mathrm{c}$ & $14 \mathrm{bc}$ & 51.72 & ס ס \\
\hline H.bacteriophora (Ht strain) & Snray & 3000 & $23 \mathrm{~cd}$ & $9 \mathrm{~d}$ & 60.68 & $4709 \mathrm{bc}$ \\
\hline & & 1500 & $33 \mathrm{~b}$ & $22 \mathrm{a}$ & 33.33 & \\
\hline H.bacteriophora (Ht strain) & Iniec & 3000 & $19 \mathrm{~d}$ & $7 \mathrm{~d}$ & 63.15 & $54>>$ \\
\hline & ction & 1500 & $26 \mathrm{c}$ & $14 \mathrm{bc}$ & 46.15 & o a \\
\hline H.bacteriophora & Spray & 1000 & $35 \mathrm{~b}$ & $22 \mathrm{a}$ & 37.14 & 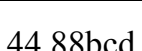 \\
\hline (Ht strain)+ Diazinon & Injection & 1000 & $38 \mathrm{a}$ & $18 \mathrm{~b}$ & 52.63 & \\
\hline H.bacteriophora & Spray & 1000 & $26 \mathrm{c}$ & $16 \mathrm{bc}$ & 38.46 & $43.03 \mathrm{bcd}$ \\
\hline (Ht strain) + Phenthoate & Injection & 1000 & $21 \mathrm{~cd}$ & $11 \mathrm{~d}$ & 47.61 & \\
\hline Diazinon ( $3 \mathrm{ml} / \mathrm{liter}$ ) & Spray & $3 \mathrm{ml} / 1$ & $36 \mathrm{a}$ & $14 \mathrm{~b}$ & 61.11 & $6765 \mathrm{ab}$ \\
\hline & Injection & $3 \mathrm{ml} / 1$ & $31 \mathrm{c}$ & $8 \mathrm{~d}$ & 74.19 & \\
\hline Phent & Spray & $3 \mathrm{ml} / \mathrm{l}$ & $25 \mathrm{~d}$ & $12 \mathrm{c}$ & 52.00 & \\
\hline Pnentnoate ( & Injection & $3 \mathrm{ml} / \mathrm{l}$ & $33 \mathrm{~b}$ & $23 \mathrm{a}$ & 30.30 & $41.15 \mathrm{Dc}$ \\
\hline
\end{tabular}

*Each value is a mean of three replicates.

The same letter (s) in columns indicates no significant differences at $P \leq 0.05$ according to Duncan's multiple range test.

Data in Table (2) revealed that applications of heterorhabditid nematodes, $H$. bacteriophora (HP88 strain), H. bacteriophora (Ht strain) and H. bacteriophora (Ar-4 strain) alone were more effective when compared with insecticides, penthoate and diazinon with percentage mortalities in Z. pyrina reached $60.86,38.46,66.67,27.27$ and 34.37 , 
consequently. S. carpocapsae (All strain) was the least effective against larvae of $Z$. pyrina when used alone with percentage mortality amounted to $23.07 \%$.

In dual application larval mortality reached $44.44 \& 50.00 ; 52.94 \& 54.16$ and $69.23 \& 64.00$ with $S$. carpocapsae (All strain), H. bacteriophora (HP88 strain) and $H$. bacteriophora (Ht strain) with penthoate and diazinon, respectively. The native nematode, H. bacteriophora (Ar-4 strain) and penthoate decreased larval mortality by $22.72 \%$. In general it could be stated that, integrating entomopathogenic nematodes with insecticides yielded high percentage of mortalities in Z. pyrina than using nematodes or insecticides alone.

Table 2. Comparison between native and imported entomopathogenic nematodes applied using spray method alone or in combination with certain insecticides for controlling Zeuzera pyrina L. on apple trees.

\begin{tabular}{|l|c|c|c|}
\hline \multicolumn{1}{|c|}{ Treatments } & $\begin{array}{c}\text { Active } \\
\text { galleries before } \\
\text { treatment }\end{array}$ & $\begin{array}{c}\text { Active } \\
\text { galleries after } \\
\text { treatment }\end{array}$ & $\%$ Mortality \\
\hline S.carpocapsae (All strain) & $13 \mathrm{c}$ & $10 \mathrm{bc}$ & $23.07 \mathrm{e}$ \\
\hline S.carpocapsae (All strain)+Diazinon & $16 \mathrm{c}$ & $8 \mathrm{c}$ & $50.00 \mathrm{bc}$ \\
\hline S.carpocapsae (All strain)+Penthoate & $18 \mathrm{c}$ & $10 \mathrm{bc}$ & $44.44 \mathrm{c}$ \\
\hline H.bacteriophora (HP88 strain) & $23 \mathrm{bc}$ & $9 \mathrm{c}$ & $60.86 \mathrm{ab}$ \\
\hline $\begin{array}{l}\text { H.bacteriophora (HP88 } \\
\text { strain)+Diazinon }\end{array}$ & $24 \mathrm{bc}$ & $11 \mathrm{bc}$ & $54.16 \mathrm{bc}$ \\
\hline $\begin{array}{l}\text { H.bacteriophora (HP88strain) } \\
+ \text { Penthoate }\end{array}$ & $17 \mathrm{c}$ & $8 \mathrm{c}$ & $52.94 \mathrm{a}$ \\
\hline H. bacteriophora (Ar-4 strain) & $12 \mathrm{c}$ & $4 \mathrm{~d}$ & $66.67 \mathrm{a}$ \\
\hline $\begin{array}{l}\text { H. bacteriophora (Ar-4 strain)+ } \\
\text { Diazinon }\end{array}$ & $54 \mathrm{a}$ & $19 \mathrm{a}$ & $64.18 \mathrm{a}$ \\
\hline $\begin{array}{l}\text { H. bacteriophora (Ar-4 } \\
\text { strain)+Penthoate }\end{array}$ & $22 \mathrm{bc}$ & $17 \mathrm{ab}$ & $22.72 \mathrm{e}$ \\
\hline H. bacteriophora (Ht strain) & $26 \mathrm{bc}$ & $16 \mathrm{a}$ & $38.46 \mathrm{~cd}$ \\
\hline $\begin{array}{l}\text { H.bacteriophora (Ht strain)+ } \\
\text { Diazinon }\end{array}$ & $26 \mathrm{bc}$ & $8 \mathrm{c}$ & $64.00 \mathrm{a}$ \\
\hline $\begin{array}{l}\text { H.bacteriophora (Ht strain)+ } \\
\text { Penthoate }\end{array}$ & $11 \mathrm{c}$ & $8 \mathrm{c}$ & $27.20 \mathrm{e}$ \\
\hline Penthoate & $32 \mathrm{~b}$ & $21 \mathrm{a}$ & $34.37 \mathrm{~d}$ \\
\hline Diazinon & & & \\
\hline
\end{tabular}

*Each value is a mean of three replicates.

The same letter (s) in columns indicate no significant differences at $P \leq 0.05$ according to

Duncan's multiple range test.

Data presented in Table (3) indicate that the degree of $Z$. pyrina susceptibility to the nematode species differed greatly according to the nematode species used either alone or in combination with the recommended dose of $B$. thuringiensis in autumn and spring. In spring $\left(26.1^{\circ} \mathrm{C}\right)$ it was evident that, nematode species of $H$. bacteriophora (HP88) was more virulent than $S$. carpocapsae (All strain) to Z. pyrina with percentage mortality 77.5 and 62.1 , respectively. Nematode species were more virulent to Z.pyrina than B. thuringiensis. It was also evident that using entomopathogenic nematode strains against $Z$. pyrina individually resulted in higher percentages of mortality than the combinations of nematodes and bacterium and /or the bacterium alone except in the case of $S$. carpocapsae with B. thuringiensis in 
spring. On the other hand, the strains of $H$. bacteriophora were more effective in high degrees of temperatures. Data revealed that there was no any synergistic or additive interaction between the nematodes and the bacterium except in the case of $S$. carpocapsae. In spring, no significant differences were found between H.bacteriophora strains (HP88 \&Ht), although some degree of significance was found between the nematode strains and the bacterium.

Table 3. Infectivity of three entomopathogenic nematodes alone or combined with Bacillus thuringensis on Zeuzera pyrina L.in two different seasons.

\begin{tabular}{|l|c|c|c|c|}
\hline \multirow{2}{*}{ Treatments } & \multicolumn{4}{c|}{$\%$ Mortality } \\
\cline { 2 - 5 } & \multicolumn{2}{|c|}{ Spring $\left(26 .{ }^{\circ} \mathrm{C}\right)$} & \multicolumn{2}{c|}{ Autumn $\left(20.9^{\circ} \mathrm{C}\right)$} \\
\cline { 2 - 5 } & $\begin{array}{c}\text { Nematode } \\
\text { or Bt alone }\end{array}$ & $\begin{array}{c}\text { Nematode } \\
+\mathrm{Bt}\end{array}$ & $\begin{array}{c}\text { Nematode } \\
\text { or Bt alone }\end{array}$ & $\begin{array}{c}\text { Nematode } \\
+\mathrm{Bt}\end{array}$ \\
\hline S. carpocapsae (All strain) & $62.1 \mathrm{~b}^{*}$ & $73.4 \mathrm{a}$ & $79.8 \mathrm{a}$ & $69.1 \mathrm{a}$ \\
\hline H.bacteriophora(HP88 strain) & $77.5 \mathrm{a}$ & $62.2 \mathrm{~b}$ & $73.5 \mathrm{~b}$ & $51.7 \mathrm{~b}$ \\
\hline H.bacteriophora(Ht strain) & $76.8 \mathrm{a}$ & $58.3 \mathrm{~b}$ & $62.6 \mathrm{c}$ & $55.4 \mathrm{~b}$ \\
\hline B. thuringensis & $30.3 \mathrm{c}$ & - & $10.0 \mathrm{~d}$ & - \\
\hline
\end{tabular}

*Each value is a mean of three replicates.

The same letter in columns indicates no significant differences at $P \geq 0.05$ according to Duncan's multiple range test.

Our previous results indicate that curative applications of entomopathogenic nematodes, $S$. carpocapsae or $H$. bacteriophora to reduce populations of $S$. myopaeformis and $Z$. pyrina, caused significant mortality and suppressed damage when applied alone or in combination with chemical and biopesticides under field conditions. Such curative treatments with recommended insecticides and EPNs may contribute to protectapple trees and reducing subsequent populations and substantial damage from larval feeding occurred in the spring and autumn. El-Kholy et al. (2014) reported that application of entomopathogenic nematodes in controlling larvae or pupae of $Z$ pyrina infested olive branches either via spraying or injection caused significant control inside the branches. By comparing nematodes and recommended insecticides for controlling $S$. myopaeformis on apple trees, our findings agree with that of Bedding and Miller (1981); Deseo et al. (1984a); Deseo and Docci (1985); Solomon (1985); Kaya and Brown (1986); Abdel-Kawy et al. (1988); Yanget al.(1990); Abdel-Kawy \& EL-Bishry (1992); Deborah et al. (1996); Shamseldean (2000) and Shamseldean et al. (2009). Rovesti et al. (1988) approved that the greater concentration of pesticide might prevent the compatibility use of the chemical with $H$. bacteriophora nematode. Shapiro-Ilan et al. (2009) indicated that nematodes applied in control of the peach tree borer, S.exitiosa reduced damage to levels similar to what is achieved with recommended chemical insecticide treatments. Bari and Kaya (1984); Deseo et al. (1984b); EL-Bishry \& Bekheit (1994); Gill \&Michael (1994); Azazy (1996) and Pasqualini et al. (1996) indicated that combination between entomopathogenic nematodes and recommended dose of $B$. thuringiensis did not result insignificantly greater control than that achieved by the nematode alone. Due to the cost of product and in some cases a change in the environment, microbial control agents are usually used to achieve economic pest control.

Our data revealed that infective juveniles (IJs) of native EPN isolates were more sensitive to tested pesticides than commercially available nematode species and $H$. bacteriophora (HP88) was the most tolerant treatment as compared to $H$. bacteriophora (Ar-4 strain) and Steinernema carpocapsae (All strain). Likewise, 
similar findings were reported by Radova (2011) and Laznik \&Trdan (2013). Grewal et al. (1998) suggested that incompatible nematicides and insecticides can be used by wait 2 and 1 weeks after application, respectively.

In conclusion, effectiveness of entomopathogenic nematodes varies depending upon the application method and concentration. However, further studies are needed under field conditions to evaluate new application methods and better compatibility of entomopathogenic nematodes with other chemicals or biopesticides may be considered as a strong option for usage in IPM.

\section{ACKNOWLEDGEMENT}

Thanks are due to Prof. Dr. Mostafa E. Mahrous, Plant Protection Department, Zagazig University for his guidance during running the experiments and writing the manuscript.

\section{REFERENCES}

Abdel-Kawy, A.; El-Kifl, T.; El-Sherif, A. and Abdel-Bary, N. (1988). Controlling the leopard moth borer Zeuuzera pyrina by the nematode Neoaplectana carpocapsae under field condition. Bulletin of the Zoological Society of Egypt 36: $108-120$.

Abdel-Kawy, A.M. and El-Bishry, M.H. (1992). Entomopathogenic nematodes as effective agents against some borer insect of orchards. Egypt. J. Appl. Sci. 7(12):180-186.

Azazy, A.M. (1996). Biological control of insects with insect parasitic nematodes. M.Sc. Thesis, Fac. Agric. Moshtohor, Zagazig Unvi. Benha Branch, Egypt. 93 pp.

Bari, M.A. and Kaya, H.K. (1984). Evaluation of the entomogenous nematode Neoaplectana carpocapsae (=Steinernema feltiae) Weiser (Rhabditida: Steinernematidae) and the bacterium Bacillus thuringiensis Berliner var. kurstaki for suppression of the artichoke plume moth (Lepidoptera: Pterophoridae). J. Econ.Entomol. 77: 225-229.

Bedding, R. A., and Akhurst, R. J. (1975). A simple technique for the detection of insect parasitic rhabditid nematodes in soil. Nematologica, 21: 109-110.

Bedding, R.A. and Miller, L.A. (1981) Use of a nematode, Heterorhabditis heliothidis to control black vine weevil, Otiorhynchus sulcatus, in potted plants. Ann. Appl. Biol. 99: 211-216.

Deborah,C.; Smith, F..; Stanton, A.G. and Robert,G.W.(1996). Evaluation of entomopathogenic nematodes as biological control against the Banded Ash clearing borer. J. Environ, Hortic. 14 (2): 67-71.

Deseo, K. V.; Govoni, I. and Miller, L. A. (1984b). Use of entomopathogenic nematodes (Rhabditida: Steinernematidae) against different species of Synanthedon (Lepidoptera: Aegeriidae) in apple and persimmon orchards. DifesadellePiante 7(5/6): 315-330.

Deseo, K.V. and Docci, R. (1985). Microbiological control against Zeuzera pyrina. (Lepidoptera: Cossidae). DifesadellePiante 8(2): 285- 291. 
Deseo, K.V.; Grassi, S.; Foschi, F. and Rovesti,L. (1984a). Asystem of biological control against the leopard moth Zeuzera pyrina (Lepidoptera: Cossidae).AttiGiornateFitopatologiche 2: 403-414.

Duncan`s, D.B. (1955). Multiple range and multiple F. tests. Biometrics 11: 1- 41.

Dutky, S.; Thompson, J. and Cantwell, G.(1964).Atechnique for the mass propagation of the DD-136 nematode. J. Insect Pathol. 6: 417-422.

Ekmen, Z.I.;Hazir, I. S.;Cakmak, Ozer, O. M.;Karagoz and Keya, H.K. (2010). Potential negative effects on biological control by Sancassania polyphllae (Acari: Acaridae) on an entomopathogenic nematode species. Biol. Control 54: 166-171.

El-Bishry, M.H and Bekheit,H. (1994). Efficacy of Steinernema carpocapsae combined with Bacillus thuringiensi sagainst the black cutworm Agrotis ipsilon. Egypt. J. Biol. Pest control 4(2): 73-78.

El-Kholy,M.Y.;Abdel-Moniem, A.S.H. and Abdelzaher, H.M.A.(2014). Persistence of entomopathogenic nematodes and fungi in soil around olive trunks and their virulence to Zeuzera pyrina L.Egypt. Acad. J. Biolog. Sci. 7(2): 57 - 61.

Gill, S, A. and Micheal, J. R. (1994). Using entomopathogenic nematodes and conventional and biorational pesticides for controlling bagworm. J. Arboriculture 20 (6) : 318-322.

Grewal, P.S.; Weber, T.A. and Betterley, D.A. (1998). Compatibility of Steinernema feltiae with chemicals used in mushroom production. Mushroom News 46: 610 .

Kaya, H. K., and Stock, S. P. (1997). Techniques in insect nematology. Pp. 281-324. in L. A. Lacey, ed. Manual of Techniques in Insect Pathology. San Diego: Academic Press.

Kaya, H.K. and Brown, L.R. (1986). Field application of entomogenous nematodes for biological control of clearing moth borers in alder and sycamore trees. J. Arboriculture 12(6): 150-154.

Laznik, Ž. and Trdan, S. (2013). The influence of insecticides on viability of entomopathogenic nematodes (Rhabditida: Steinernematidae and Heterorhabtidae) under laboratory conditions. Pest. Manag. Sci. doi: 10.1002/ ps. 3614 .

Mannion,C. M. ; Winkler, H. E.; Shapiro, D.I. and Gibb T. (2000). Interaction between halofenozide and the entomopathogenic nematode Heterorhabditis maretalus for control of Japanese bettle (Coleoptera : Scarabaeidae) larvae. J. Econ.Entomol. 93(1):48-53.

MSTAT version 4 (1987). A software program for the design and analysis of agronomic research experiments. Michigan, USA, Michigan State University.

Pasqualini, E; Antropoli, A. and Civolani,S. (1996). Recent experiments in the control of Zeuzerapyrina with chemical and microbiological products. Informatore Agrario. 52(19): 67-69.

Radova, S. (2011). Effect of selected pesticides onsurvival and virulence of two nematode species . Polish. J. Environ. Stud. 20 (1): 181-185. 
Rovesti, L.;Heinzpeter E. W.;Tagliente, F. and Deseo, K. V. (1988).Compatibility of pesticides with entomopathogenic nematode Heterorhabditis bacteriophora Poinar (Nematoda: Heterorhabditidae). Nematologica 34(4):462-476.

Shamseldean, M. M. (2000). Laboratory bioassays and field application of entomopathogenic nematode isolates and species belonging to the genera Heterorhabditis and Steinernema against the leopard moth Zeuzera pyrina. J. Agric. Sci. Mansoura Univ. 25: 8151-8161.

Shamseldean, M. M.; Hasanain, S. A. and Rezk, M. Z. A. (2009). Virulence of entomopathogenic nematodes against lepidopterous pests of horticultural crops in Egypt. Proceedings of the 4th Conference on RecentTechnologies in Agriculture "Challenges of Agriculture Modernization" Vol. 1, pp. 74-84.

Shapiro-Ilan, D.I.; Cottrell,T. E.; Mizell, R. F.; Horton, D. L. and J. Davis (2009). A novel approach to biological control with entomopathogenic nematodes: Prophylactic control of the peach tree borer, Synanthedon exitiosa. Biol. Control $48: 259-263$.

Solomon, J. D. (1985). Comparative effectiveness of gallery injected insecticides and fumigants to control carpenter worms (Lepidoptera: Coccidae) and oak clearing borer (Lepidoptera: Sessiidae). J. Econ.Entomol.78: 485-488.

Woodring, J. L. and Kaya, H.K.(1988).Steinernematid and heterorhabditid nematodes :a hand book of techniques. Southern Cooperative Series Bulletin331, Arkansas Agricultural Experiment Station, Fayetteville, Arkansas,1-30pp.

Yang, H.W.; Zhang, S.G.; Zhang, G.Y.; Huang,J. S. and Zheng, H.C.(1990). Control of leopard moth, Zeuzera multistrigata leuconota (Lepidoptera: Cossidae) on casuarina trees by using sponge plugs carrying Steinernema feltiae. Chinese J. Biol. Control 6 (4): 157-160. 


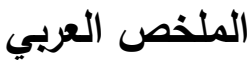

Synanthedo myopaeformis Borkh المكافحة الحقلية لكل من حفار ساق الحلويات رائقة الأجنح

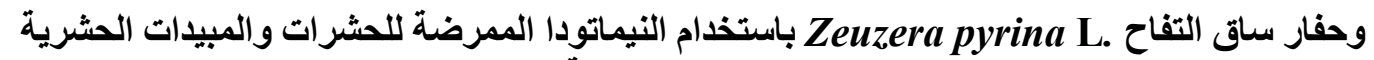

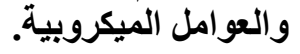

رمضان محمد أحمد العشرى ا محمد فاضل محمود الثيخ باحمد محمد عزازى ب ألفت السبد عرفه بr

$$
\begin{aligned}
& \text { 1 - قسم وقاية النبات - كلية الزراعة - جامعة الزقازيق- مصر. }
\end{aligned}
$$

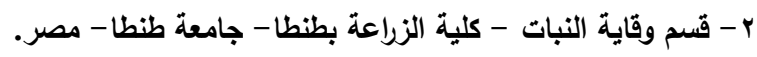

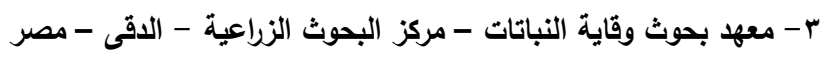

أجريت ثلاث تجارب حقلية لتقييم كفاءة سلالتين محلتين من النيماتودا الممرضة للحشرات المعزولتين من

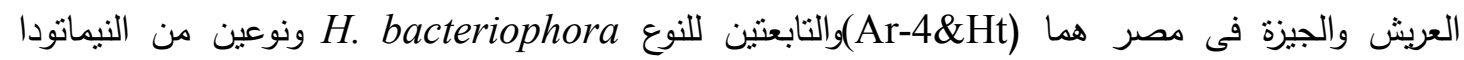

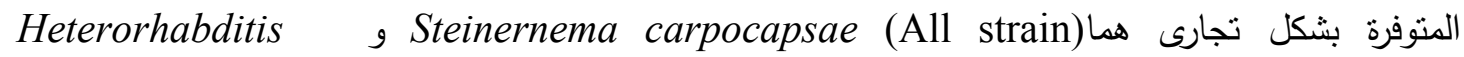
bacteriophora (HP88 strain)

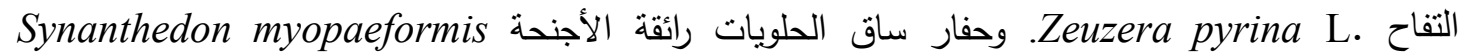
Borkh لكل من المبيد الميكروبى Bacillus thuringiensis (Diple2X) والميبدين الحشريين diazinon

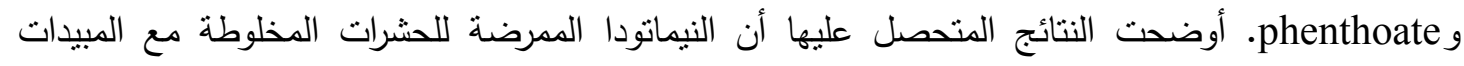

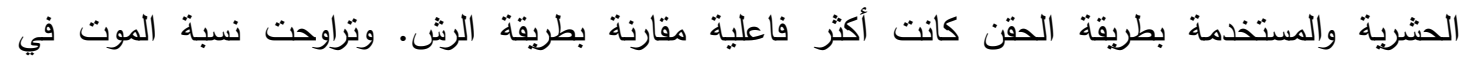

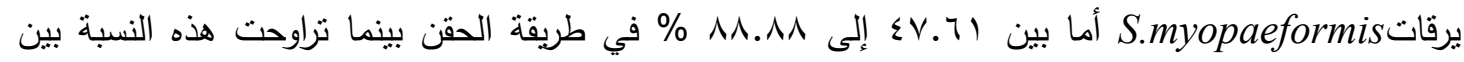

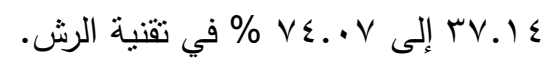
وعند مقارنة فعالية النيمانودا الممرضة للحشرات المثاث المعزولة محليا وبين تلك الأنواع المستوردة والتي استخدمت فى مكافحة.Z. pyrina L بتقنية الرش ، كانت نسبة الموت الناتجة من خلط النيماتودا المحلية H. bacteriophora (Ar-4 strain) و H.bacteriophora (Ht strain) Diazinon و هي (r. Penthoate

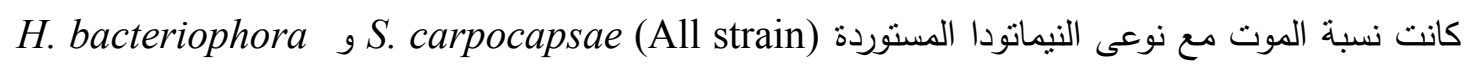
(HP88 strain)

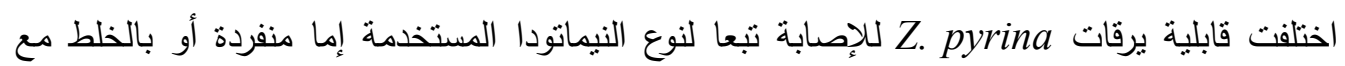

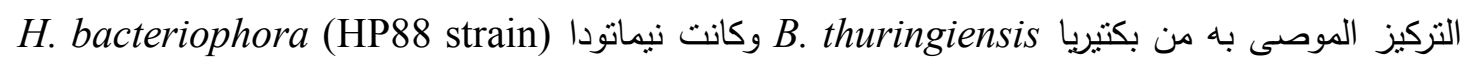

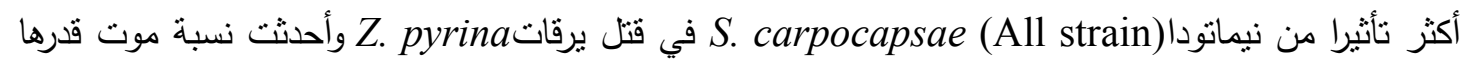

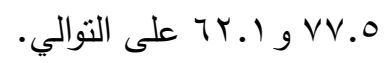

